\title{
Role of quercetin and arginine in ameliorating nano zinc oxide-induced nephrotoxicity in rats
}

\author{
Laila M Faddah ${ }^{1}$, Nayira A Abdel Baky ${ }^{1,3^{*}}$, Nouf M Al-Rasheed ${ }^{1}$, Nawal M Al-Rasheed ${ }^{1}$, Amal J Fatani ${ }^{1}$ and \\ Muhammad Atteya ${ }^{2}$
}

\begin{abstract}
Background: Nanoparticles are small-scale substances $(<100 \mathrm{~nm})$ with unique properties. Therefore, nanoparticles pose complex health risk implications. The objective of this study was to detect whether treatment with quercetin (Qur) and/or arginine (Arg) ameliorated nephrotoxicity induced by two different doses of nano zinc oxide (n-ZnO) particles.

Method: ZnO nanoparticles were administered orally in two doses (either $600 \mathrm{mg}$ or $1 \mathrm{~g} / \mathrm{Kg}$ body weight/day for 5 conscutive days) to Wister albino rats. In order to detect the protective effects of the studied antioxidants against $\mathrm{n}-\mathrm{ZnO}$ induced nepherotoxicity, different biochemical parameters were investigated. Moreover, histopathological examination of kidney tissue was performed.

Results: Nano zinc oxide-induced nephrotoxicity was confirmed by the elevation in serum inflammatory markers including: tumor necrosis factor alpha (TNF-a), interleukin-6 (IL-6); and C-reactive protein (CRP). Moreover, immunoglobulin (IGg), vascular endothelium growth factor (VEGF), and nitric oxide (NO) were significantly increased in rat serum. Serum urea and creatinine levels were also significantly increased in rats intoxicated with n-ZnO particles compared with the control group. Additionally, a significant decrease in the non-enzymatic antioxidant reduced glutathione (GSH) was shown in kidney tissues and serum glucose levels were increased. These biochemical findings were supported by a histopathological examination of kidney tissues, which showed that in the animals that received a high dose of $\mathrm{n}-\mathrm{ZnO}$, numerous kidney glomeruli underwent atrophy and fragmentation. Moreover, the renal tubules showed epithelial desquamation, degeneration and necrosis. Some renal tubules showed casts in their lumina. Severe congestion was also observed in renal interstitium. These effects were dose dependent. Cotreatment of rats with Qur and/or Arg along with n-ZnO significantly improved most of the deviated tested parameters.
\end{abstract}

Conclusions: The data show that Qur has a beneficial effect against $\mathrm{n}$ - $\mathrm{ZnO}$ oxidative stress and related vascular complications. Also, its combination with Arg proved to be even more effective in ameliorating nano zinc oxide nephrotoxicity.

Keywords: nano- Zinc oxide, Qur, Tumor necrosis factor alpha (TNF-a), Interleukin-6 (IL-6), C-reactive protein (CRP), Arg, Vascular endothelium growth factor (VEGF)

\footnotetext{
* Correspondence: nayira@ksu.edu.sa

${ }^{1}$ Pharmacology Department, Faculty of Pharmacy, King Saud University,

Riyadh Saudi Arabia

${ }^{3}$ Department of Pharmacology, Faculty of Pharmacy, King Saud University,

P.O. Box. 22452, Riyadh 11495, Saudi Arabia

Full list of author information is available at the end of the article
} 


\section{Background}

The rapid growth of the nanotechnology industry has led to wide-scale production and application of engineered nanoparticles (NPs). NPs are not only used in industry and medicine but are also increasingly used in various consumer products such as cosmetics, sunscreens, and food products [1]. However, the properties that make them useful are also the cause of concern [2-4]. The ability of NPs to induce toxicity has been attributed to their increased surface reactivity $[5,6]$. The small particle size of NPs creates a large surface area per unit mass and makes them more reactive in a cell. It has also been proposed that the an increase in the surface area of NPs greatly increase their ability to produce reactive oxygen species (ROS) $[7,8]$. NPs can enter the human body through different routes such as inhalation, ingestion and injection $[9,10]$. They may then translocate to blood causing adverse biological reactions in several organs, which are considered to be the secondary major sites of interaction $[11,12]$. The kidney is particularly susceptible to xenobiotics because of its high blood supply and its ability to concentrate toxins. Alteration of the total glutatahione GSH (tGSH) level in cells can be considered an indication of adaptive response to cell to oxidative damage. Nano-ZnO particles at high concentrations significantly decreased the renal tGSH level compared with control values, which indicates functional damage to kidney tissues.

Considering the hazards of treatment failure, drug resistance and heavy costs associated with current renal therapy, medicinal plants have attracted the interest of many researchers in this field. Qur has been found to protect kidney tissues against age-related NF- $\mathrm{kB}$ activity in the kidneys that leads to increased oxidative stress [13]. Moreover, Qur protects the kidneys during ischemia and reperfusion by preserving higher levels of the enzyme xanthine dehydrogenase relative to the injurious enzyme xanthine oxidase [14]. Moreover, it was found that Qur protected the cells against hydrogen peroxideinduced oxidative stress and calcium dysregulation that prevents cell damage [15].

Arginine (Arg) is a nonessential amino acid that has numerous functions in the body. Arg plays an important role in cell division, healing of wounds and in immune function [16-18]. Oral supplementation of L-Arg has been shown to increase precursors for the synthesis of nitric oxide (NO) [19], reduce the healing time of injuries, [20], and decrease blood pressure [21]. Dietary intervention with $\mathrm{L}$-Arg resulted in amelioration of a number of experimental kidney diseases, such as those caused by subtotal nephrectomy, as well as diabetic nephropathy, [22]. Nitric oxide (NO) synthesis requires Arg, and plays a pivotal role in regulating kidney function in patients with high blood pressure or various renal disorders [23]. Impairment of NO production in these vascular epithelial cells is a characteristic feature of heart failure, and it can cause harm to the kidneys.

The objective of this study was to assess renal cell responses to the manufactured NPs to show their potential toxic biological responses and investigate the renoprotective effect of Qur and Arg.

\section{Methods}

\section{Chemicals}

The 50-nm $\mathrm{ZnO}$ powder was purchased from Sigma Co. (USA). All other chemicals used in the study were of analytical grade, and were from Sigma and Merck.

\section{Animals and treatments}

Fifty Wistar albino rats (170-200 g) were used. The rats were obtained from the Experimental Animal Care Center, College of Pharmacy, King Saud University. Animals were kept in special cages on a constant 12-h light/12-h dark cycle with air conditioning. Temperature ranged from $20-22^{\circ} \mathrm{C}$ with $60 \%$ humidity. Rats were fed standard rat pellet chow and had free access to tap water ad libitum for one week before the experiment. Animal utilization protocols were performed in accordance with the guidelines provided by the Experimental Animal Laboratory and approved by the Animal Care and Use Committee of King Saud University, College of Pharmacy. After one week acclimation, the rats were kept fasting over night before treatment and were randomly divided into two classes according to the dose of $\mathrm{ZnO}$-nanoparticle that was administered.

Class I consisted of five groups (ten rats per group):

G1: normal healthy animals

G2-G5: animals orally administered $600 \mathrm{mg} / \mathrm{kg}$ body weight/day $\mathrm{n}-\mathrm{ZnO}$ for 5 days [24], and divided as follows:

G2:ZnO-intoxicated animals with a low oral dose (600 mg/kg/day) daily for 5 days.

G3: ZnO-intoxicated animals administered Qur

(200 mg/kg) daily [25].

G4: ZnO-intoxicated animals administered Arg

(200 mg/kg) [26] daily.

G5: ZnO-intoxicated animals co-administered Arg

(200 mg/kg) and Qur (100 mg/kg) daily.

Class II consisted of four groups (G6-G9; ten rats per group) orally administered $1 \mathrm{~g} / \mathrm{kg}$ body weight/day for 5 days $\mathrm{n}-\mathrm{ZnO}[25]$ and divided as follows:

G6: $\mathrm{ZnO}$-intoxicated animals with a high oral dose ( $1 \mathrm{~g} / \mathrm{kg} /$ day) daily for 5 days. 
G7: ZnO-intoxicated animals administered Arg

(200 mg/kg) daily.

G8: ZnO-intoxicated animals administered Qur

(200 mg/kg) daily.

G9: ZnO-intoxicated animals co-administered Arg

(200 mg/kg) and Qur (200 mg/kg) daily.

Qur and/or Arg were orally administered daily for three weeks from the beginning of the experiment. The body weights of rats were recorded before and after the administration period.

At $24 \mathrm{~h}$ after the last dose administration, rats were sacrificed by decapitation, and blood was collected. Serum was separated by centrifugation at $3000 \mathrm{rpm}$. for $10 \mathrm{~min}$ and kept at $-80^{\circ} \mathrm{C}$. Both kidneys were harvested through a midline incision, rinsed in cold isotonic saline, homogenized, and frozen at $-80^{\circ} \mathrm{C}$ for estimations of GSH content. Three kidneys from each group were kept in $10 \%$ formalin for histopathological examination.

\section{Serum biochemical analysis}

\section{Determination of TNF-a level}

The concentration of inflammatory cytokines (TNF- $\alpha$ ) in serum was determined using commercially available enzyme-linked immunosorbent assay ELISA kits following the instructions supplied by the manufacturer (DuoSet kits, R\&D Systems; Minneapolis, MN, USA).

\section{Determination of CRP level}

CRP was measured with latex-enhanced immunonephelometry on a Behring BN II Nephelometer (Dade Behring). In this assay, polystyrene beads coated with rat monoclonal antibodies bind CRP present in the serum sample and form aggregates. The intensity of scattered light is proportional to the size of the aggregates and thus concentration of CRP present in the sample. The intraassay and interassay coefficients of variation for CRP were $3.3 \%$ and $3.2 \%$, respectively. The lower detection limit of the assay was $0.15 \mathrm{mg} / \mathrm{L}$ [27].

\section{Determination of VEGF level}

The level of VEGF in serum was determined at $492 \mathrm{~nm}$ by quantitative colorimetric sandwich ELISA (R\&D systems, UK) in accordance with the manufacturer's instructions [28]. Concentrations were calculated using a standard curve generated with specific standards provided by the manufacturer.

\section{Determination of IgG level}

The IgG level was measured in serum using a sandwich ELISA. The capture antibody was goat anti-rat IgG (Kirkegaard \& Perry Laboratories, Inc., Gaithersburg, MD). Standards were prepared from rat IgG (Sigma Chemical Co., St. Louis, MO). Goat anti-rat IgG peroxidase conjugates were diluted 1:250 in PBS/BSA (from Kirkegaard \& Perry Laboratories, Inc.) and used as detecting antibodies. The chromogenic substrate used was 2,2' -azino-di [3-ethyl-benzthiazoline sulfonate] (ABTS; Kirkegaard \& Perry Laboratories, Inc.). Color development was detected via optical density at $405 \mathrm{~nm}$ using an automated ELISA plate reader (Bio-tek Instruments, Inc., Winooski, VT) and immunoglobulin concentrations were determined by comparison of sample color development to standard curves (Kineticalc, Bio-tek Instruments, Inc.).

\section{Determination of IL-6 level}

The IL- 6 levels were measured by ultra-sensitive ELISA (Quantikine HS Human IL-6 Immunoassay; R\&D Systems, Minneapolis, MN) with an analytical CV of $6.3 \%$ and a detection level of $0.04 \mathrm{pg} / \mathrm{mL}$ [29].

\section{Determination of total nitrite/nitrate level}

Serum total nitrite/nitrate level concentration (as an indirect measurement of NO synthesis) was assayed using Griess reagent (sulfanilamide and N-1-naphthylethylenediamine dihydrochloride) in acidic medium [30].

\section{Determination of glucose level}

Glucose level was estimated using the method of Trinder 1969[31].

Determination of serum urea, creatinine and uric acid level Serum samples were assayed for urea, creatinine, and uric acid by using standard diagnostic kits.

\section{Determination of renal reduced glutathione (GSH) level}

Kidney tissue levels of acid-soluble thiols and reduced GSH were determined calorimetrically at $412 \mathrm{~nm}$ [32]. Homogenates were precipitated with trichloroacetic acid, and after centrifugation, supernatants were used for the estimation of protein thiols (Protein-SH) expressed as $\mu \mathrm{mol} / \mathrm{mg}$ wet tissue.

\section{Histopathological techniques}

Samples of kidney tissues were collected, and were fixed in a $4 \%$ formaldehyde solution for $24 \mathrm{~h}$. They were dehydrated in ascending grades of ethyl alcohol, cleared in xylene, and embedded in paraffin. Paraffin blocks were cut at $4-\mu \mathrm{m}$ thickness, then fixed on glass slides. Sections were stained with hematoxylin and eosin (H\&E) by the following method: they were hydrated using washes with descending grades of alcohol, then hematoxylin was added to stain the nuclei, and afterwards eosin was added to the cytoplasm. Another set of unstained slides were stained with Masson's trichrome after de-waxing and rehydration of unstained slides. Sections were immersed in Weigert's working hematoxylin for $10 \mathrm{~min}$ then 
washed with water for $5 \mathrm{~min}$, and was rinsed in distilled water. They were then stained with Biebrich scarlet for $5 \mathrm{~min}$ followed by rinsing in distilled water. Slides were immersed in phosphotungstic/ phosphomolybdic acid for $10 \mathrm{~min}$. The solution was discarded. After that sections were transferred directly into Light Green for $5 \mathrm{~min}$ followed by rinsing in distilled water. The sections were immersed in $10.1 \%$ acetic acid solution for $1 \mathrm{~min}$ to visualize deposition of collagen fibers. This usually makes the sample turn green [33]. The histological changes were estimated semi-quantitatively, as being mild, moderate, or marked by microscopic examination of histological sections.

\section{Statistical analysis}

Data are presented as mean \pm S.D. Statistical analysis was performed using an Instat-3 computer program (Graph pad software Inc, San Diego, CA). One way analysis of variance (ANOVA) followed by Bonferroni multiple tests was used to determine the differences between means of different groups. The level of significance was set at $p \leq 0.05$.

\section{Results}

The current investigation revealed that the administration of $\mathrm{n}-\mathrm{ZnO}$ particles, either in low or high doses, significantly elevated $(p<0.001)$ serum inflammatory markers (TNF- $\alpha$, CRP, and IL-6) levels compared with normal control values (Table $1 \& 2$ ). Moreover, $\mathrm{n}-\mathrm{ZnO}$ treatment significantly increased $(p<0.001)$ serum IgG, VEGF, and glucose levels. $\mathrm{n}-\mathrm{ZnO}$ treatment also increased total nitrite concentration (Figure 1 and Figure 2), with a concomitant decrease in renal GSH content compared with normal control values $(p<0.001)$ (Figure 3 and Figure 4). After estimation of renal function para- meters (serum urea, creatinine and uric acid), there were no significant changes in the serum levels of $\mathrm{n}$ - $\mathrm{ZnO}$-intoxicated rats as compared with normal control group $(p<0.05)$, with the exception of urea and creatinine levels (Table 3 and 4). Generally, the large dose of $\mathrm{n}-\mathrm{ZnO}$ induced significant alteration in the previous parameters than that of the low dose. Oral administration of Qur, Arg or a combination of both significantly reduced $(p<0.001)$ serum TNF- $\alpha$, CRP, IL-6 compared with $\mathrm{n}-\mathrm{ZnO}$-intoxicated rats (Table $1 \& 2$ ). Interestingly, CRP level decreased significantly with Arg treatment. However, the combination of the two agents showed a more powerful effect in alleviating the rise of inflammatory mediator levels. Additionally, serum IgG, VEGF, nitric oxide, and glucose levels decreased significantly $(p<0.001)$, with a concomitant increase in renal GSH content $(p<0.001)$ (Figure $1-4)$. Arg alone, or in combination with Qur, significantly decreased serum creatinine level as compared with rats intoxicated with high dose of $\mathrm{n}-\mathrm{ZnO}$ particles $(p<0.05)$ (Table 4 and). There was no significant change either in body weight, kidney weight, or in kidney/body weight $\%$ between all the groups (Tables 5 and 6).

The results of these biochemical markers were supported by the histopathological examination of kidney tissues stained with HE. This examination revealed that the animals which received a low dose of $\mathrm{n}-\mathrm{ZnO}$ showed moderate atrophy and fragmentation of many glomeruli compared with control group (Figure 5A). Few renal tubules showed epithelial desquamation, degeneration and necrosis and tubular casts in their lumina. Vascular congestion was also observed in renal interstitium (Figure 5B), but was less than that observed in intoxicated animals with a high dose of $\mathrm{n}-\mathrm{ZnO}$. Quercetin treatment showed minimum protective effects on the renal tissues of intoxicated rats (Figure $5 \mathrm{C}$ ). However, n-

Table 1 Effect of Qur and/or Arg treatment on serum inflammatory markers level in intoxicated rats with a low dose of n-ZnO particles

\begin{tabular}{|c|c|c|c|c|c|}
\hline Parameters & Control & n-Zno & Qur & Arg & Qur + Arg \\
\hline TNF- $\boldsymbol{a}(\mathrm{pg} / \mathrm{ml})$ & $242.7 \pm 6.1$ & $361.6 \pm 9.2^{a}$ & $299.5 \pm 3.1^{\text {*b \# \# }}$ & $276.12 \pm 4.05^{* b}$ & $300.6 \pm 4.1^{* b}$ \# \# \\
\hline CRP $(\mathrm{ng} / \mathrm{ml})$ & $3.16 \pm 0.1$ & $4.4 \pm 0.20^{a}$ & $3.4 \pm 0.04^{* c}$ & $3.3 \pm 0.04^{* c}$ & $3.1 \pm 0.7^{*} \#$ \# \\
\hline IL-6 (pg/ml) & $31 \pm 2.098$ & $44.33 \pm 1.2^{a}$ & $42.86 \pm 0.49^{\text {a\# }}$ & $35.3 \pm .811^{\mathrm{a}^{*}}$ & $35.66 \pm 1.21^{a^{*}}$ \\
\hline
\end{tabular}

Data are presented as mean \pm S.D. from 10 rats, $^{a} P \leq 0.001,{ }^{b} P \leq 0.01,{ }^{c} P \leq 0.05$ compared with the normal group, ${ }^{*} P \leq 0.001$ compared with the n-ZnO-intoxicated group, ${ }^{\#} P \leq 0.001,{ }^{\# \#} P \leq 0.01$ compared with the combination group, respectively, using ANOVA followed by Bonferroni as a post-ANOVA test.

Table 2 Effect of Qur and/or Arg treatment on serum inflammatory marker levels in intoxicated rats with a high dose of $\mathrm{n}$-ZnO particles

\begin{tabular}{|c|c|c|c|c|c|}
\hline Parameters & Control & $\mathrm{n}-\mathrm{ZnO}$ & Qur & Arg & Qur + Arg \\
\hline TNF- $\mathbf{a}(\mathrm{Pg} / \mathrm{ml})$ & $242.7 \pm 6.1$ & $371.7 \pm 6.1^{a}$ & $293.6 \pm 4.3^{* b}$ & $322.18 \pm 1.9^{* b \#}$ & $314.1 \pm 2.9^{* b \#}$ \\
\hline CRP (ng/ml) & $3.16 \pm 0.1$ & $4.6 \pm 0.11^{a}$ & $2.9 \pm 0.05^{*}$ & $3.0 \pm 0.07^{*}$ & $3.7 \pm 0.055^{* b \# \# ~}$ \\
\hline IL-6 (ng/ml) & $31 \pm 2.098$ & $49.57 \pm 1.01^{a}$ & $39.41 \pm 0.62^{a^{*}}$ & $41.80 \pm 0.28 a^{* \#}$ & $44.94 \pm 1.02 a^{* \# \# \# ~}$ \\
\hline
\end{tabular}

Data are presented as mean \pm S.D. for 10 rats, ${ }^{a} P \leq 0.001,{ }^{b} P \leq 0.01$ compared with the normal group, ${ }^{*} P \leq 0.001$ compared with the $n$-ZnO intoxicated-group, ${ }^{\#}$ $P \leq 0.05$, \#\# $P \leq 0.01$, \#\#\# $P \leq 0.01$ compared with the combination group, respectively, using ANOVA followed by Bonferroni as a post-ANOVA test. 

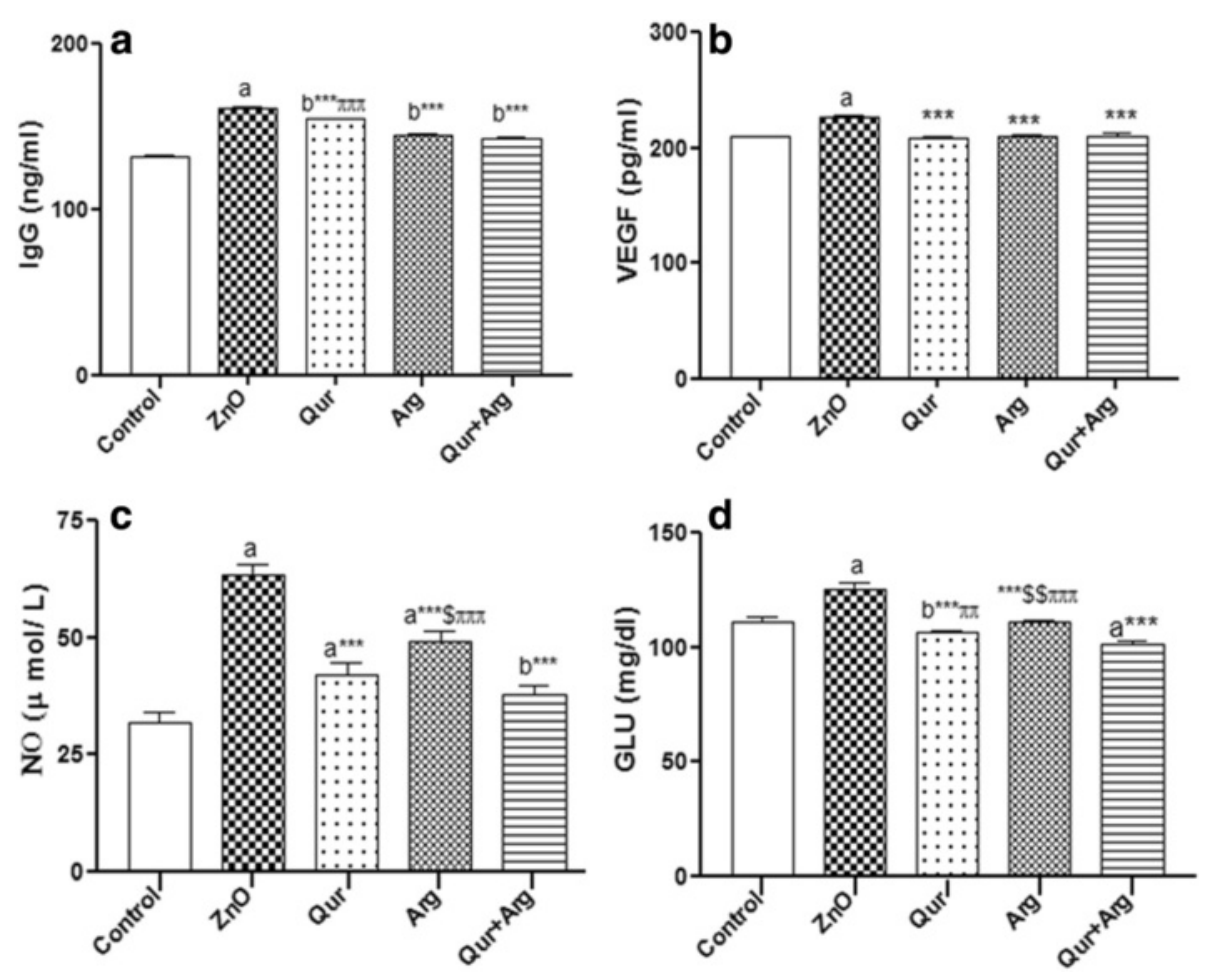

Figure 1 Effect of Qur and/or Arg treatment on serum IgG (a), VEGF (b), total nitrate/nitrite (c), and glucose (d) concentrations in intoxicated rats with low dose of $\mathbf{n}$-ZnO particles. Values are expressed as mean \pm S.D. ${ }^{a} P<0.001,{ }^{b} P<0.01$ compared with the normal control group, ${ }^{* * *} P<0.001$ compared with the $\mathrm{n}$-ZnO-intoxicated group, ${ }^{\$ \$} P \leq 0.01, \$ P \leq 0.05$ compared with the Qur-treated group, ${ }^{\text {, }}{ }^{\$ \pi} P \leq 0.001$, пा $P \leq 0.01$ compared with the combination group, respectively, using ANOVA followed by Bonferroni as a post-ANOVA test.

$\mathrm{ZnO}$ intoxicated animals treated with Arg showed a major improvement in the histopathological destruction observed in kidney tissues. This was shown by minimal glomerular shrinkage and lower rates of tubular epithelial desquamation and degeneration (Figure 5D). Intoxicated animals co-treated with quercetin and Arg showed mild histological changes, in a form of mild glomerular fragmentation and epithelial exfoliation in few renal tubules (Figure 5E).

The kidneys of rats treated with a high dose of $\mathrm{n}-\mathrm{ZnO}$ showed massive atrophy and fragmentation of numerous glomeruli. The renal tubules also showed epithelial desquamation, degeneration and necrosis. Numerous renal tubules showed casts in their lumina. In addition, sever congestion was observed in the renal interstitium (Figure 6B). However, the animals which received $\mathrm{n}-\mathrm{ZnO}$ and quercetin showed histopathological changes in the kidney similar to those detected in the untreated group (Figure $6 \mathrm{C}$ ). The animals that received $\mathrm{n}-\mathrm{ZnO}$ and Arg showed histopathological changes in the kidney similar to those detected in the control group (Figure 6D). However, animals that received $\mathrm{n}-\mathrm{ZnO}$, quercetin and arginine showed mild histological changes, with fragmentation of few glomeruli and epithelial exfoliation in few renal tubules (Figure 6E).

Kidney tissues of animals intoxicated with $\mathrm{n}-\mathrm{ZnO}$ and stained with Masson's trichrome showed moderate (with low dose-intoxicated rats) to marked (with high dose-intoxicated rats) increase of collagen fiber deposits in the interstitial tissue (Figure $7 \mathrm{~B}$ and Figure $8 \mathrm{~B}$, respectively) compared with the normal control group (Figure 7A and Figure 8A). Animals that received n- $\mathrm{ZnO}$ and quercetin showed a moderate increase of interstitial collagen deposition (Figure 7C and Figure 8C). However, Arg-treated groups showed minimum collagen deposition similar to the control group (Figsure 7D and 8D). Qur- and Arg-treated groups showed a mild increase in collagen deposition (Figure 7E and Figure 8E).

\section{Discussion}

Nanoparticles were found to reach the systemic circulation and disseminate to several organs such as the liver, spleen and kidneys [3,34]. Kidneys play an important role in eliminating xenobiotics from the body and NPs absorbed in the systemic circulation can be excreted by renal clearance $[35,36]$. Few studies have described the 


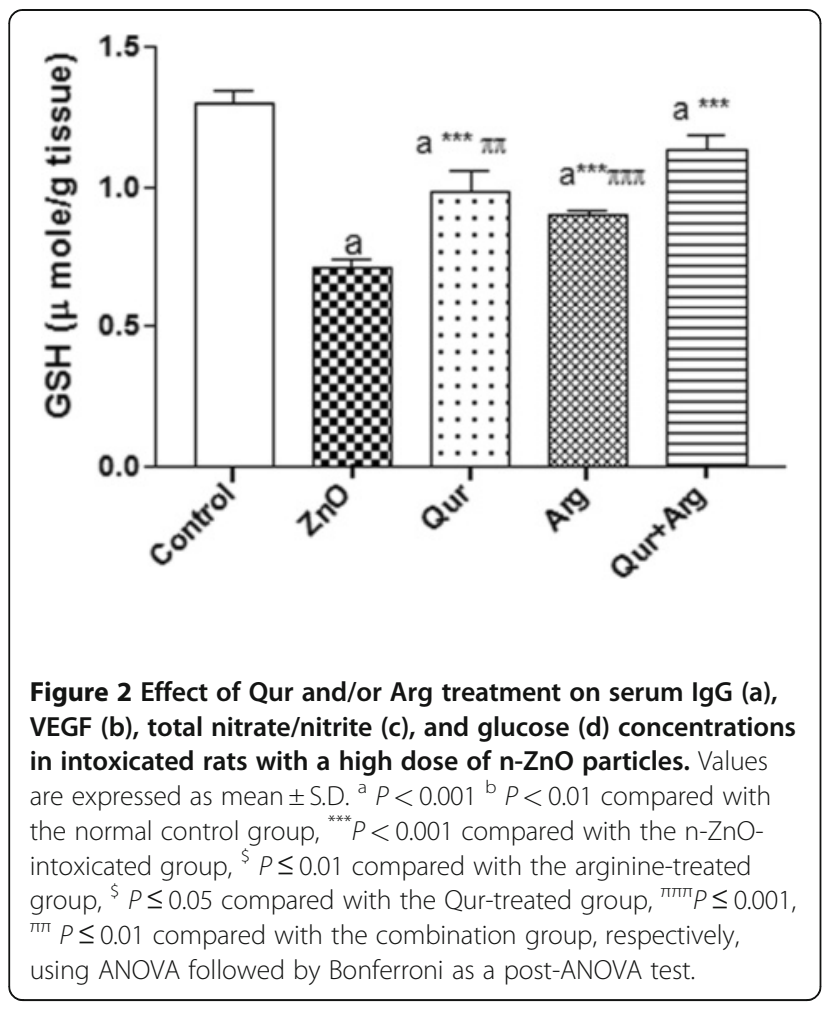

potential toxicity of NPs to renal tubular and glomerular targets [7,37]. Kidney damage with morphological, pathological, and cellular changes leading to kidney dysfunction after exposure to NPs has been studied [12,38].

In the present study, low and high doses of $\mathrm{ZnO}$ NPs significantly elevated inflammatory cytokine levels, including TNF $\alpha-$, IL-6, and CRP in rat serum compared with the normal control group. Levels of VEGF, NO and IgG were also significantly elevated. These findings were accompanied with a dose dependent increase in serum urea and creatinine levels in $\mathrm{n}-\mathrm{ZnO}$ intoxicated rats compared with normal control rats. Tosu et al. [39]. elucidated the inflammatory effects of $50-$ and $100-\mathrm{nm}$ $\mathrm{ZnO}$ particles on human umbilical vein endothelial cells (HUVECs). Nano-ZnO concentrations of $\leq 3 \mu \mathrm{g} / \mathrm{ml}$ resulted in increased cell proliferation, while those of $\leq 45 \mu \mathrm{g} / \mathrm{ml}$ caused dose-dependent increases in oxidized glutathione levels. Nano-ZnO particles induced a dosedependent increase in the expression of the intercellular adhesion molecule (ICAM-1) protein, an indicator of vascular endothelium inflammation, and caused marked increases in NF- $\kappa B$ activity. Additionally, TNF- $\alpha$, a typical inflammatory cytokine, induced ICAM-1 expression in an NF- $\mathrm{kB}$-dependent manner. $\mathrm{ZnO}$ also synergistically

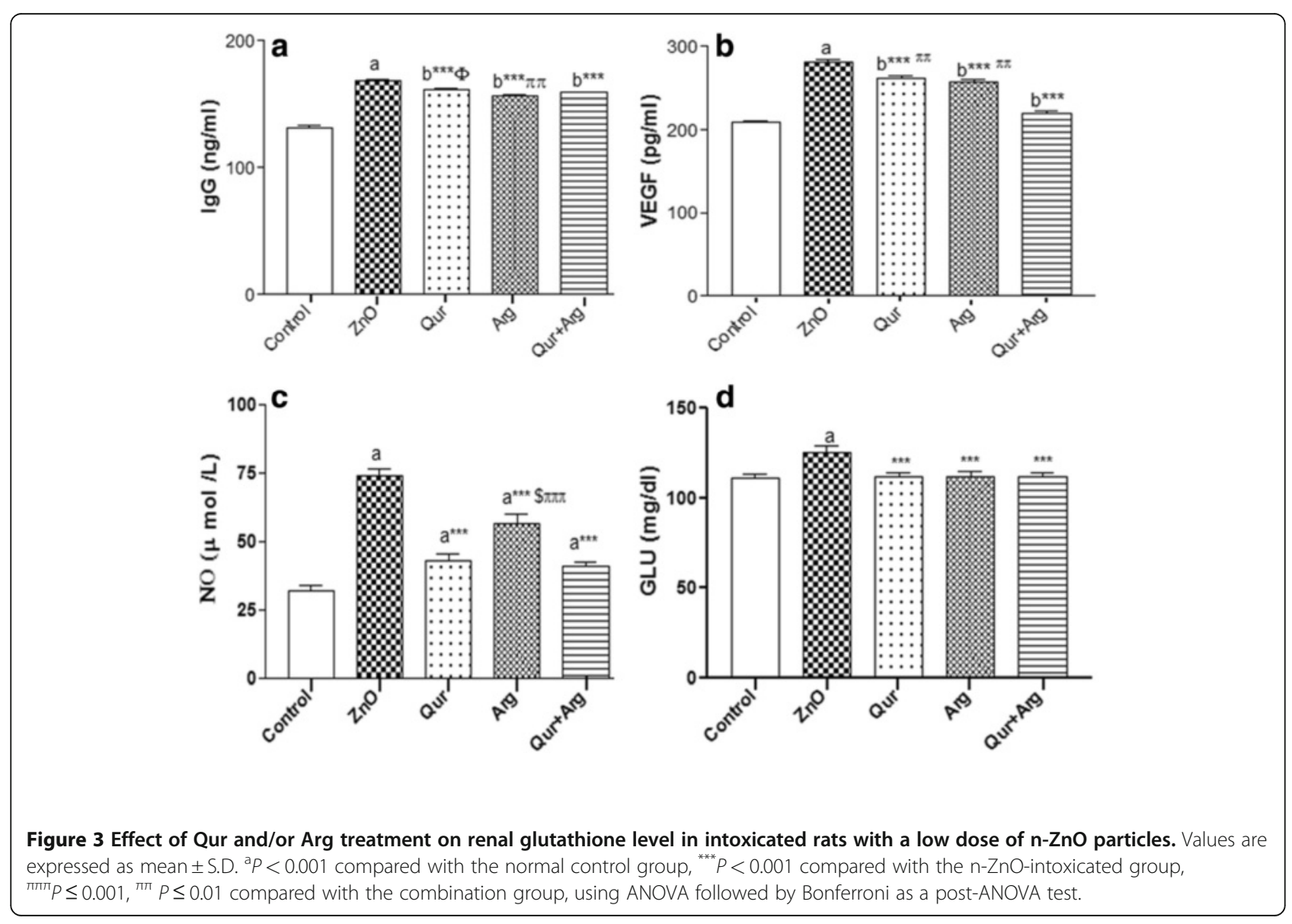




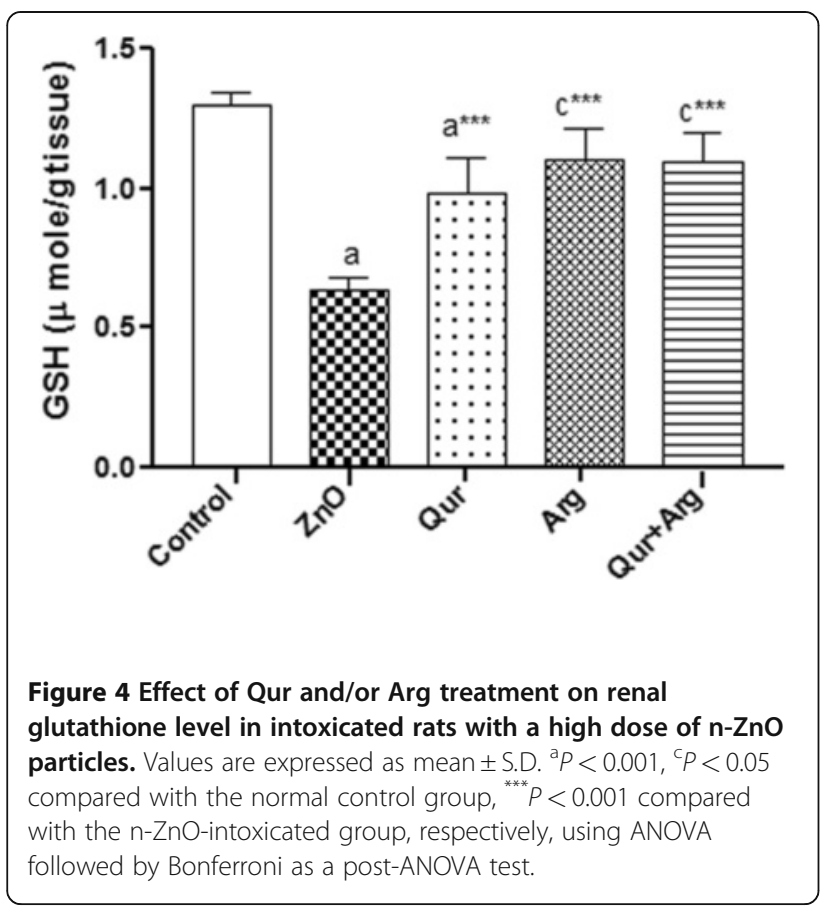

enhanced TNF- $\alpha$-induced ICAM-1 expression. Moreover, Fine et al. [40] found that exposures to low concentrations of zinc oxide elevated circulating levels of different cytokines, which could account for the symptoms of the metal fume fever syndrome. This is in accordance with the present study as low and high doses of $\mathrm{ZnO}$ NPs significantly elevated cytokines (TNF- $\alpha$ and IL-6) levels in rat serum compared with normal control group.

Growing evidence indicates the beneficial role of a nutrient mixture of L-Arg and Qur in inhibiting the inflammatory response by down-regulating pro- inflammatory cytokine protein expression levels [41]. Moreover, Mostafavi et al. [42] found that Qur and Arg plays a protective role against the imbalance elicited between the production of free radicals and antioxidant defense systems, and suggested that a combination of these two antioxidants may find clinical application where cellular damage is a consequence of reactive oxygen species.

The current study shows that cytokine (TNF- $\alpha$ and IL-6) levels were reduced post-Qur treatment compared with the $\mathrm{n}-\mathrm{ZnO}$ treated group. This was in accordance with the results of Behling et al. [43] who found that cisplatin-treated rats presented a transitory increase in plasma creatinine levels, tubular cell necrosis and increased immunostaining for vimentin, alpha-SM-actin, fibronectin, and NF- $\mathrm{kB}$ in the renal cortex and outer medulla. Meanwhile, Qur treatment attenuated renal functional, histological and immunohistochemical alterations induced by cisplatin [43]. Other studies showed that $\mathrm{NF}-\kappa \mathrm{B}$ plays a pivotal role in progressive kidney diseases by regulating the accumulation of macrophages [44]. Qur potently inhibited NF- $\mathrm{kB}$ activation in cultured rat proximal tubular cells (PTCs), because NF- $\kappa B$ regulates inflammatory signaling and adhesion molecules in PTCs. Additionally, Qur is known to modulate the action of several inflammatory cytokines that are of particular concern to transplant recipients, including IL-1 $\beta$, IL-2, IL-6, IL-15 and TNF- $\alpha$ [45-47]. Hushmendy et al. [48] found that Qur significantly inhibited cytokine levels and T-cell proliferation, suggesting that it may be effective in reducing transplant rejection. These findings may explain earlier findings that administration of Qur inhibited tubular injury and the elevation in inflammatory cytokine levels.

In the present study Arg significantly reduced the elevated levels of inflammatory cytokines (TNF- $\alpha$ and IL-6)

Table 3 Effect of Qur and/or Arg treatment on serum creatinine, urea, and uric acid levels in intoxicated rats with a low dose of $\mathrm{n}-\mathrm{ZnO}$ particles

\begin{tabular}{llllll}
\hline Parameters & Control & n-ZnO & Qur & Arg & Qur + Arg \\
\hline Creatinine $(\mathrm{mg} / \mathrm{dl})$ & $0.4 \pm 0.075$ & $0.53 \pm 0.077$ & $0.47 \pm 0.078$ & $0.44 \pm 0.027$ & $0.42 \pm 0.069$ \\
Urea $(\mathrm{mg} / \mathrm{dl})$ & $21.4 \pm 4.88$ & $32.3 \pm 6.83^{a}$ & $28.6 \pm 5.47$ & $27.9 \pm 2.92$ & $27.2 \pm 4.21$ \\
Uric acid $(\mathrm{mg} / \mathrm{dl})$ & $2.1 \pm 0.55$ & $2.51 \pm 0.58$ & $2.44 \pm 0.78$ & $2.23 \pm 0.21$ & $2.06 \pm 0.54$
\end{tabular}

Data are presented as mean \pm S.D. for 10 rats, $^{a} P \leq 0.05$ compared with normal group using ANOVA followed by Bonferroni as a post-ANOVA test.

Table 4 Effect of Qur and/or Arg treatment on serum creatinine, urea, and uric acid levels in intoxicated rats with a high dose of $\mathrm{n}-\mathrm{ZnO}$ particles

\begin{tabular}{llllll}
\hline Parameters & Control & n-ZnO & Qur & Arg & Qur + Arg \\
\hline Creatinine $(\mathrm{mg} / \mathrm{dl})$ & $0.4 \pm 0.075$ & $0.63 \pm 0.087^{\mathrm{a}}$ & $0.51 \pm 0.066$ & $0.50 \pm 0.033^{*}$ & $0.50 \pm 0.045^{*}$ \\
Urea $(\mathrm{mg} / \mathrm{dl})$ & $21.4 \pm 4.88$ & $35.2 \pm 5.88^{\mathrm{b}}$ & $29.8 \pm 4.57$ & $28.8 \pm 2.02$ & $28.2 \pm 5.21$ \\
Uric acid $(\mathrm{mg} / \mathrm{dl})$ & $2.1 \pm 0.55$ & $3.02 \pm 0.53$ & $2.84 \pm 0.98$ & $2.93 \pm 0.61$ & $2.36 \pm 0.55$ \\
\hline
\end{tabular}

Data are presented as mean \pm S.D. from 10 rats, $^{a} P \leq 0.001,{ }^{b} P \leq 0.01$ compared with the normal group, ${ }^{*} P \leq 0.05$ compared with the n-ZnO-intoxicated group, respectively, using ANOVA followed by Bonferroni as a post-ANOVA test. 
Table 5 Effect of Qur and/or Arg treatment on body weight, kidney weight, and kidney/body weight \% in intoxicated rats with a low dose of $\mathrm{n}$-ZnO particles

\begin{tabular}{|c|c|c|c|c|}
\hline \multirow[b]{2}{*}{ Control } & \multicolumn{2}{|c|}{ Body Weight (g)Initial Final } & \multirow{2}{*}{$\begin{array}{l}\text { Kidney Weight (g) } \\
1.22 \pm 0.164\end{array}$} & \multirow{2}{*}{$\begin{array}{l}\text { Kidney/Body Weigh \% } \\
0.454 \pm 0.090\end{array}$} \\
\hline & $251.6 \pm 9.39$ & $271.6 \pm 23.73$ & & \\
\hline n-Zno & $250.4 \pm 14.15$ & $280.6 \pm 6.50$ & $1.14 \pm 0.114$ & $0.405 \pm 0.034$ \\
\hline Qur & $242.4 \pm 14.84$ & $271 \pm 19.30$ & $1.3 \pm 0.282$ & $0.482 \pm 0.098$ \\
\hline Arg & $238.2 \pm 12.27$ & $262.8 \pm 19.66$ & $1.22 \pm 0.083$ & $0.528 \pm 0.074$ \\
\hline Qur + Arg & $235.6 \pm 11.19$ & $264.2 \pm 17.41$ & $1.18 \pm 0.192$ & $0.484 \pm 0.081$ \\
\hline
\end{tabular}

Table 6 Effect of Qur and/or Arg treatment on body weight, kidney weight, and kidney/body weight \% in intoxicated rats with a high dose of $\mathrm{n}-\mathrm{ZnO}$ particles

\begin{tabular}{llll}
\hline & \multicolumn{2}{l}{ Body Weight $(\mathbf{g})$ Initial Final } & Kidney Weight (g) \\
\hline Control & $251.6 \pm 9.39$ & $271.6 \pm 23.73$ & $1.22 \pm 0.164$ \\
n-ZnO & $232.4 \pm 14.87$ & $262.6 \pm 22.94$ & $0.94 \pm 0.209$ \\
Qur & $249.4 \pm 22.39$ & $272.8 \pm 37.79$ & $0.454 \pm 0.090$ \\
Arg & $242 \pm 19.583$ & $268.6 \pm 19.57$ & $1.34 \pm 0.243$ \\
Qur + Arg & $232 \pm 28.87$ & $265 \pm 41.085$ & $1.12 \pm 0.211$ \\
\hline
\end{tabular}

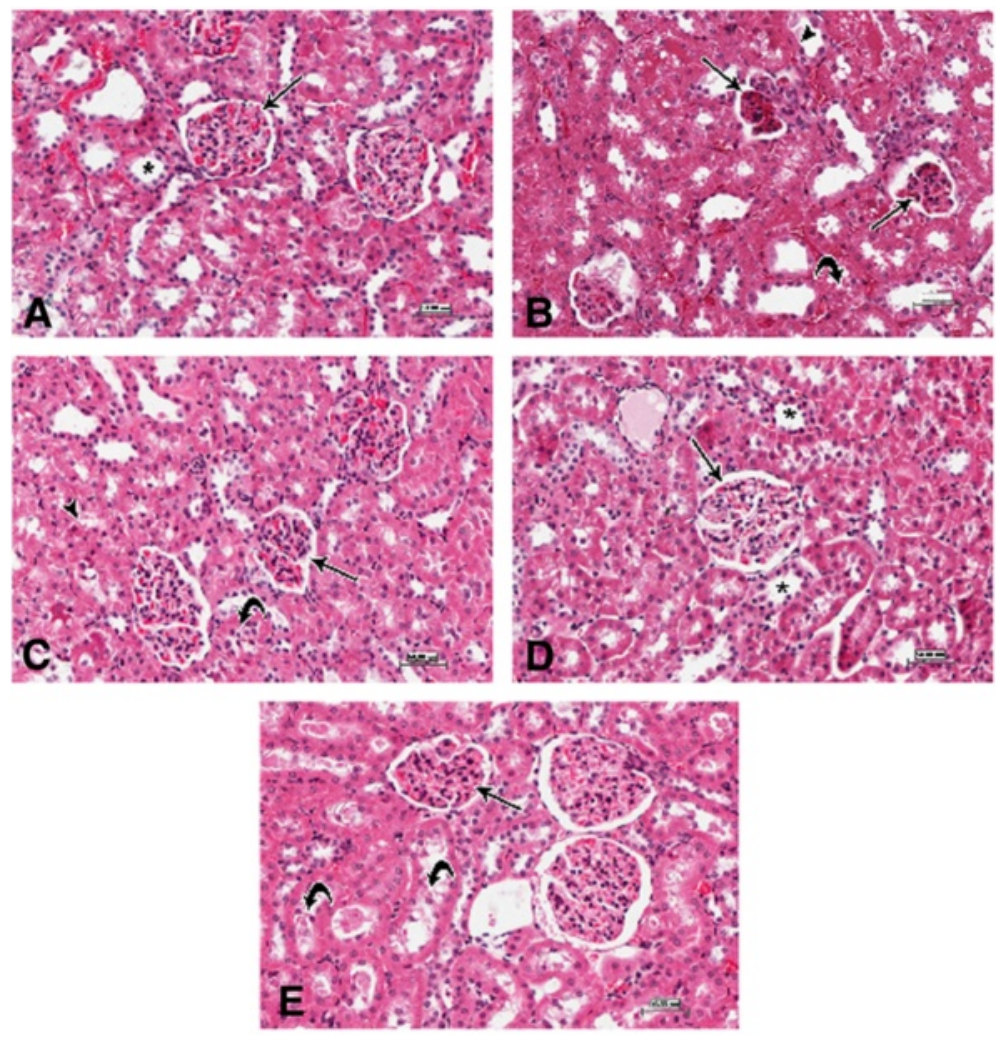

Figure 5 Photomicrographs of kidney sections stained with hematoxylin and eosin (scale bars $=50 \mu \mathrm{m}$ ), showing: (A) control group, normal architecture of renal corpuscles with their glomeruli (arrow) and renal tubules (asterisk); (B) intoxicated group with $600 \mathrm{mg} / \mathrm{kg}$ body weight/day $\mathrm{n}-\mathrm{ZnO}$ particles for 5 days, shrinkage and fragmentation of many glomeruli (arrows) with many renal tubules showing degeneration, necrosis (arrowhead) and exfoliation of their lining epithelium (curved arrow); (C) Qur-treated group, shrinkage and fragmentation in many glomeruli (arrow) with necrosis (arrowhead) and exfoliation of lining epithelial cells of many renal tubules (curved arrow); (D) Arg-treated group, normal architecture of renal corpuscles with their glomeruli (arrow) as well as normal renal tubules (asterisk); and (E) Qur + Arg-treated group, few glomeruli with shrinkage and fragmentation, and few renal tubules with epithelial cell exfoliation (curved arrows). 


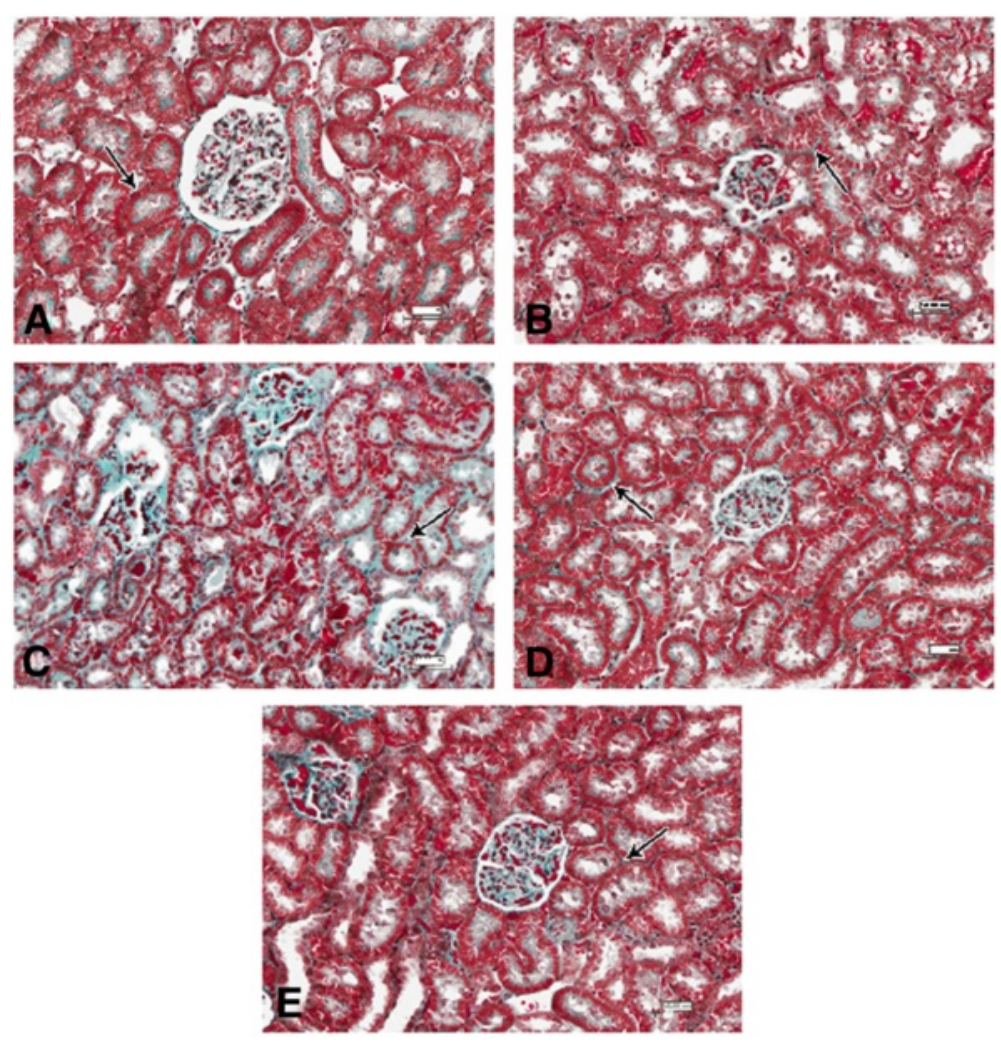

Figure 6 Photomicrographs of kidney sections stained with hematoxylin and eosin (scale bars $=50 \mu \mathrm{m}$ ), showing: (A) control group, normal renal corpuscles with normal glomeruli (arrow) and renal tubules (asterisks); (B) intoxicated group with $1 \mathrm{~g} / \mathrm{kg}$ body weight/ day for $\mathbf{5}$ days with $\mathrm{n}$-ZnO particles, shrinkage and fragmentation of many glomeruli (arrows). In addition many renal tubules show degeneration, necrosis (arrowheads) and exfoliation of their lining epithelium (curved arrow). (C) Qur-treated group, many glomeruli reveal shrinkage and fragmentation (arrows) with degeneration, necrosis (arrowheads) and exfoliation of epithelial lining cells of the renal tubules (curved arrow). (D) Arg-treated group: Almost all the renal corpuscles with their glomeruli (arrows) as well as the renal tubules (asterisks) are similar to normal architecture. (E) Qur + Arg-treated group, there were few renal tubules with degeneration, necrosis (arrowhead) and exfoliation of their lining epithelial cells (curved arrow).

compared with $\mathrm{n}-\mathrm{ZnO}$ treated group. Moreover, Arg alone or in combination with Qur significantly decreased serum creatinine level as compared with rats intoxicated with a high dose of $\mathrm{n}-\mathrm{ZnO}$ particles. This was attributed to the fact that Arg has various metabolic and immunologic effects and has been considered to be conditionally essential, particularly under inflammatory and oxidative stress [49]. It has protective effects against oxidative stress and inflammation in different pathological conditions [42]. It can modulate the inflammatory response by modulating the production of inflammatory mediators, such as C-reactive protein as well as cytokine release from activated immune competent cells which play a crucial role in the progression of the pathology [50].

Elevation of CRP level post_n- $\mathrm{ZnO}$ administration compared with the normal control group in the current work was in accordance with the work of Kim et al. [27], who clarify that CRP is related to the incidence of many pathological condition as coronary heart disease, hypertension, and inflammation. Both Qur and/or Arg treatments reduced CRP level compared with $\mathrm{n}-\mathrm{ZnO}$ intoxicated group. This is in agreement with Kleemann et al. [51] who clarified that dietary intake of flavonoids such as Qur was associated with lower CRP levels. Moreover, Wu et al. [50] found that Arg can modulate inflammatory response by modulating the production of inflammatory mediators, such as C-reactive protein.

The increase in the circulating IgG in rat serum intoxicated with both doses of $\mathrm{ZnO}$-NPs is an immune response induced by NPs toxicity. It is suggested that the increase in the circulating antibodies are the result of the production of different inflammatory cytokines, including TNF- $\alpha$, with potential impact on immunoglobulin production during inflammation. These results may indicate tha $\mathrm{tZnO}$-NPs induced inflammatory kidney injury through production of the inflammatory 


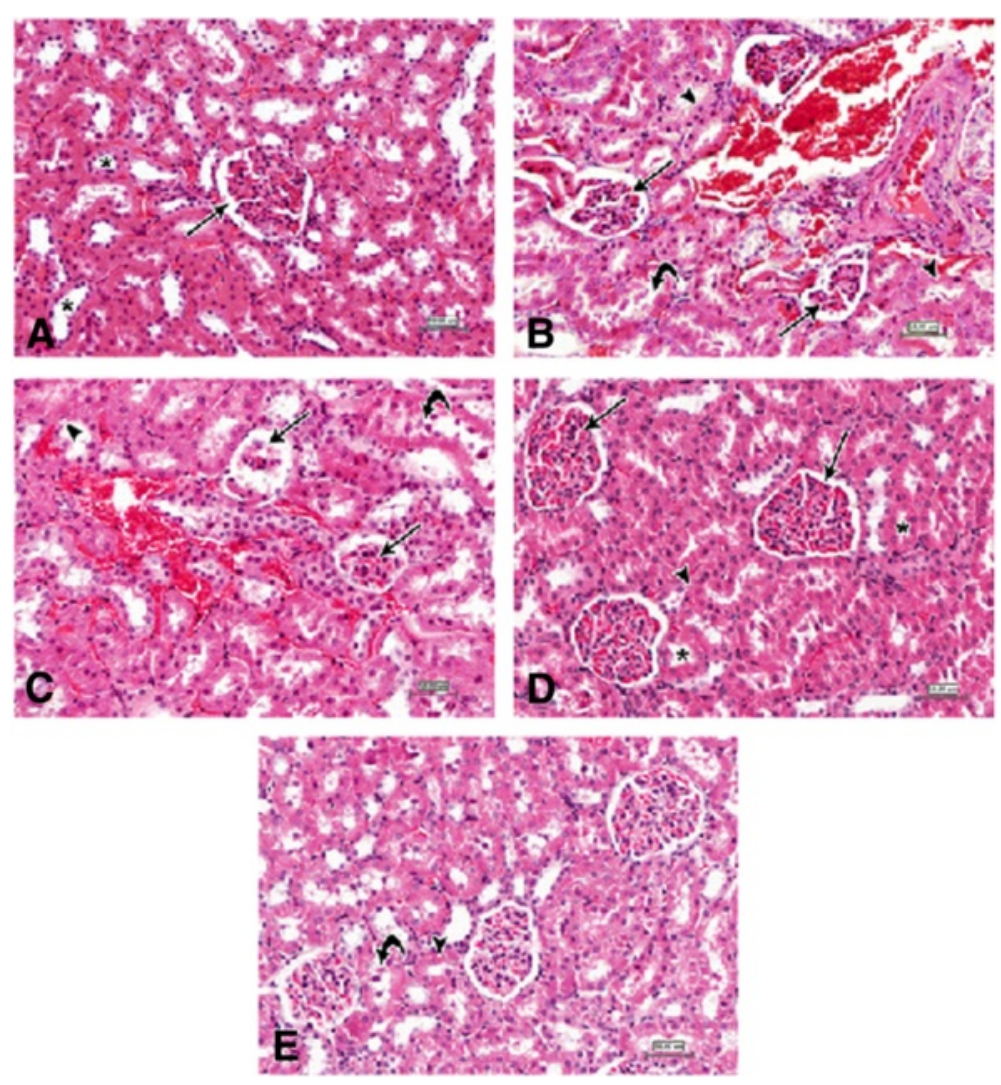

Figure 7 Photomicrographs of kidney sections from normal and intoxicated rats with $600 \mathrm{mg} / \mathrm{kg}$ body weight/day $\mathrm{n}$-ZnO particles for 5 days stained with Masson trichrome (scale bars $=\mathbf{5 0} \boldsymbol{\mu m}$ ). All groups revealed normal distribution of a small amount of collagen fibers (arrow) between the renal tubules in the interstitium.

mediators [52]. The IgG level was reduced by Arg and Qur treatments. This may explain the role of these agents to suppress the release of inflammatory mediators.

There was a significant increase in serum nitrite/nitrate level in $\mathrm{n}-\mathrm{ZnO}$ intoxicated rats. High amounts of $\mathrm{NO}$ are released from the inducible NO synthase (iNOS) isoform in response to inflammatory stimuli from a variety of cell types [53,54]. Renal proximal tubule and inner medullary collecting duct cells can produce NO via expression of an inducible isoform of nitric oxide synthase [55]. Mesangial cells and invading immune cells are capable of expressing iNOS upon stimulation with TNF- $\alpha$ and IL-1b. The release of large amounts of NO in the glomerulus may lead to the progression of renal failure during several forms of glomerulonephritis [56]. Increased tissue factor expression is thought to play a significant role in the development of multiorgan system failure in acute injury [57]. Vascular endothelial growth factor (VEGF), which is a potent mitogen for endothelial cells, has been reported to be expressed in several tissues, including the kidney. The expression of various tissue factors, cytokines, and chemokines in response to inflammatory tissue injury stimulates VEGF synthesizing cells such as platelets, immune cells, and inflammatory cells [58-60]. Besides its mitogenic properties, VEGF is able to promote angiogenesis and increase vascular leakage $[61,62]$. However, it was found that stimulation of angiogenesis may contribute to the transition from acute to chronic inflammation. Some investigations have revealed that new vessels can significantly contribute to perpetuation of the inflammatory response by expressing chemokines and adhesion molecules promoting the recruitment of inflammatory cells [63]. This suggests the possibility that TNF- $\alpha$ and VEGF might act synergistically to potentiate kidney injury and/or systemic organ dysfunction [64], and explain the elevation in TNF- $\alpha$, $\mathrm{NO}$, and VEGF levels post- $\mathrm{n}-\mathrm{ZnO}$ treatment compared with the control group.

The use of anti-angiogenic agents may then represent an attractive alternative therapeutic tool to prevent or significantly reduce fibrosis progression .The protective 


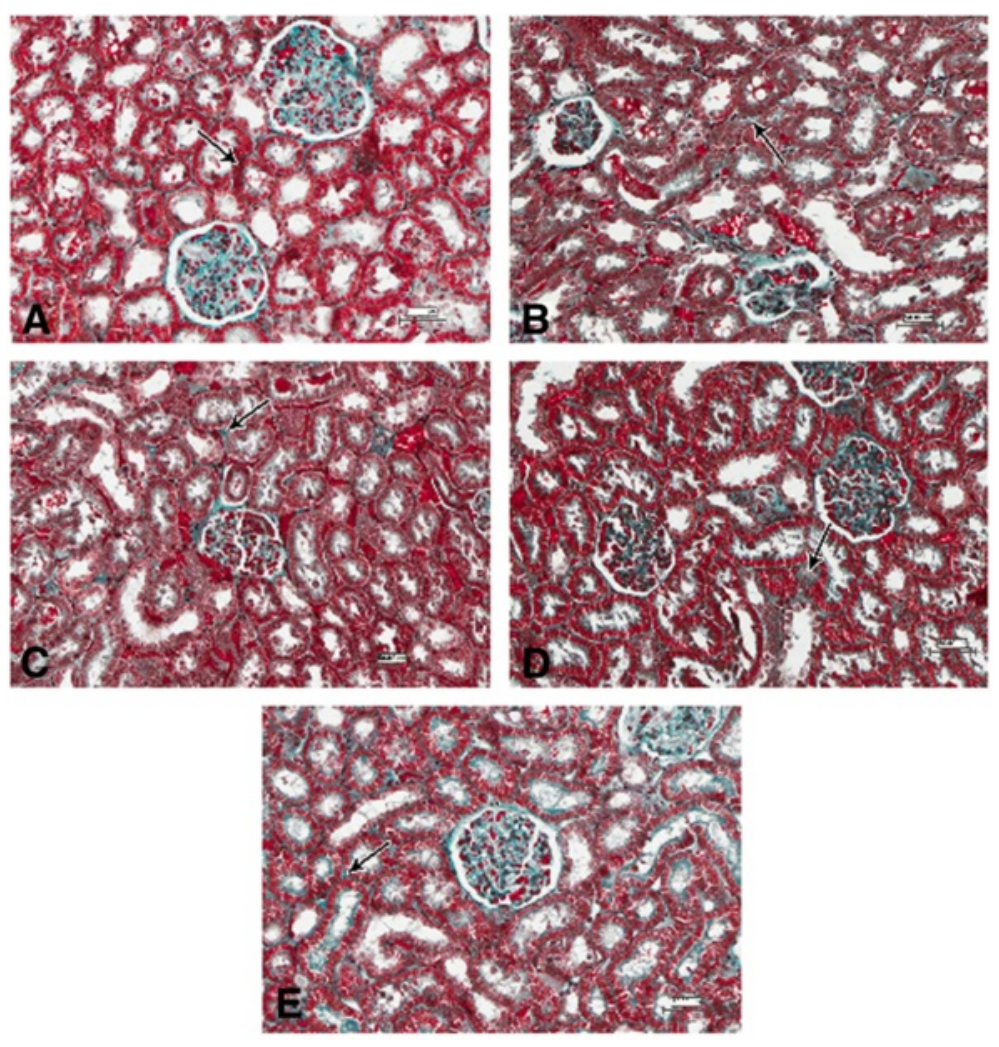

Figure 8 Photomicrographs of kidney sections stained with Masson trichrome (scale bars $=50 \mu \mathrm{m}$ ), showing the Control group (A) with normal distribution of a small amount of collagen fibers (arrow) between the renal tubules. (B) Intoxicated group with $1 \mathrm{~g} / \mathrm{kg}$ body weight/day for 5 days with $\mathrm{n}$-ZnO particles. There was an evident increase of deposition of collagen fibers in the interstitium (arrow). (C) Qurtreated group, an obvious increase of collagen fibers between the renal tubules (arrow). (D) Arg-treated group, there was a small amount of collagen fibers between the renal tubules (arrow). (E) Qur + Arg-treated group: Mild increase in collagen fibers between the renal tubules (arrow).

ingestion of the agents used alone or in combination, markedly reduced the dramatic increase in this angiogenic biomarker in sera of $\mathrm{n}-\mathrm{ZnO}$ intoxicated rats, suggesting their anti-angiogenic beneficial action. Previous investigations revealed the role of Arg in reducing VEGF expression [65].

Serum nitrite/nitrate was significantly decreased upon treatment of intoxicated animals with Qur or with the Qur and Arg combination but not with Arg alone. However, the increase in NO level in the Arg-treated group was accompanied by a significant increase in renal GSH content of $\mathrm{n}-\mathrm{ZnO}$ intoxicated rats. The $\mathrm{n}-\mathrm{ZnO}$ treated group showed a significant increase in free radical generation after $\mathrm{n}-\mathrm{ZnO}$ treatment with resultant damaging effect on the kidney tissue as evidenced from histopathological examination (Figure 5-8). Data of Arg-treated group suggests that pharmacological increases in NO levels did not exacerbate the increase in free radical formation. High levels of NO or Arg in the Arg-treated group may be protective, probably due to their property of scavenging free radicals as well as inhibiting xanthenes oxidase $(\mathrm{XO})$ enzyme [66].

In the present study, GSH levels were significantly reduced after $\mathrm{n}-\mathrm{ZnO}$ treatment, while treatment with both Arg and Qur increased renal GSH content when compared with the $\mathrm{n}-\mathrm{ZnO}$ treated group. This was attributed to the antioxidant properties of both agents. The Qur antioxidant effect is based on its ability to quench hydrogen peroxide [14]. Qur reduces platelet aggregation and adhesion by reducing hydrogen peroxide production [14]. Qur attenuated cyclosporine-induced oxidative stress by restoring the activity of the antioxidative enzymes glutathione peroxidase and catalase, preventing its nephrotoxic action and kidney damage [67]. Arg significantly reduced lipid peroxidation and increased GSH content in the heart tissue of exhaustively exercised rats [68]. These findings augment the current results in which the combination of both agents significantly decreased kidney damage by synergistically increasing cellular levels of GSH. 
These biochemical findings were supported by the histopathological examination of kidney tissues, which clarified that animals received either low or high doses of $\mathrm{n}-\mathrm{ZnO}$ particles showed moderate to massive atrophy and fragmentation of numerous glomeruli. The renal tubules showed epithelial desquamation, degeneration and necrosis. Some renal tubules showed casts in their lumina. Sever congestion was also observed in renal interstitium. These hazardous effects were dosedependent. Co-treatment of n-ZnO_intoxicated rats with Qur or Arg, significantly improved most of the deviated histopathological parameters. The combination of Qur and Arg nearly prevented the damaging effect of $n-\mathrm{ZnO}$ intoxication that was manifested microscopically by extensive improvements in the histological features of kidney cells in the form of fragmentation of few glomeruli and epithelial exfoliation in few renal tubules as well as marked reduction in deposition of collagen fibers in the interstitial tissues.

\section{Conclusion}

In this study, the ability of ZnO-NPs to exert different cytotoxic effects was demonstrated. This was evidenced from the elevation in inflammatory cytokines (TNF, IL6, and CRP), IgG, VEGF, creatinine levels, as well as NO induction. These altered parameters contribute to nephrotoxic potential of $\mathrm{n}-\mathrm{ZnO}$ particles which was clear from the histopathological examination. Treatment with either Arg, Qur, or their combination successively alleviated the alterations in the previous biomarkers, as well as effectively reducing the histopathological changes in $\mathrm{n}$ - $\mathrm{ZnO}$ cytotoxic rats. This may be related to their ability to attenuate the extent of liberation of ROS and inflammatory cytokines induced by such nanoparticles.

\section{Competing interests}

The authors declare that they have no competing interests.

\section{Authors' contributions}

LF: participated in the design of the study, participated in the experimental part of the study, evaluated the therapeutic effect of the used antioxidants on different biological function. NA: carried out the experimental part of the study, participated in the design of the study, performed the statistical analysis, drafted the manuscript. NR: conceived the study, and participated in its design and coordination. NR: participated in manuscript design and coordination. AF: participated in manuscript design and coordination. MA: participated in the histopatholigical part. All authors read and approved the final manuscript.

\section{Acknowledgments}

The authors gratefully acknowledge the Strategic Technique Program of the National Plane for Science, Technology, and Innovation (NPST) in Riyadh, Kingdom of Saudi Arabia for the financial support of this work in the form of Research Fellowship.

\section{Author details}

'Pharmacology Department, Faculty of Pharmacy, King Saud University, Riyadh Saudi Arabia. ${ }^{2}$ Anatomy Department and Stem Cell Unit, Faculty of Medicine, King Saud University, Riyadh, Saudi Arabia. ${ }^{3}$ Department of
Pharmacology, Faculty of Pharmacy, King Saud University, P.O. Box. 22452, Riyadh 11495, Saudi Arabia.

Received: 15 July 2011 Accepted: 2 April 2012

Published: 2 May 2012

\section{References}

1. Van Tassel K A and Goldman R: The Growing consumer exposure to nanotechnology in everyday product: Regulating innovative technologies in light of lessons from the past. Connecticut Law Review, Vol. 44, No. 2, 2011

2. Oberdorster G, Ferin J, Lehnert BE: Correlation between particle size, in vivo particle persistence and lung injury. Environ Health Perspect 1994, 102(5):73-179.

3. Oberdörster G, Maynard A, Donaldson K, Castranova V, Fitzpatrick J, Ausman K, Carter J, Karn B, Kreyling W, Lai D, Olin S, Monteiro-Riviere N, Warheit D, Yang $\mathrm{H}$ : Principles for characterizing the potential human health effects from exposure to nanomaterials: elements of a screening strategy. Part Fibre Toxicol 2005 Oct, 2:8.

4. Oberdorster G, Oberdorster E, Oberdorster J: Nanotoxicology: an emerging discipline evolving from studies of ultrafine particles. Environ Health Perspect 2005, 113:823-839.

5. Donaldson K, Tran L, Jimenez LA, Duffin R, Newby DE, Mills N, MacNee W, Stone V: Combustion-derived nanoparticles: A review of their toxicology following inhalation exposure. Part Fibre Toxicol 2005 Oct, 2:10.

6. Colvin $\mathrm{VL}$ : The potential environmental impact of engineered nanomaterials. Nat Biotechnol 2003, 21(10):1166-1170.

7. Møller $\mathrm{P}$, Jacobsen NR, Folkmann JK, Danielsen PH, Mikkelsen L, Hemmingsen JG, Vesterdal LK, Forchhammer L, Wallin H, Loft S: Role of oxidative damage in toxicity of particulates. Free Radic Res 2010, 44(1):1-46.

8. Li N, Sioutas C, Cho A, Misra C, Sempf J, Wang M, Oberley T, Froines J, Nel A: Ultrafine particulate pollutants induce oxidative stress and mitochrondrial damage. Environ Health Perspect 2003, 111:455-460.

9. Koeneman BA, Zhang Y, Westerhoff P, Chen Y, Crittenden JC: C DG: Toxicity and cellular responses of intestinal cells exposed to titanium dioxide. Cell Biol Toxicol 2010, 26(3):225-238.

10. Nemmar A, Hoet PH, Vanquickenborne B, Dinsdale D, Thomeer M, Hoylaerts MF, Vanbilloen H, Mortelmans L, Nemery B: Passage of inhaled particles into the blood circulation in humans. Circulation 2002, 105(4):411-414.

11. Johnston HJ, Hutchison G, Christensen FM, Peters S, Hankin S, Stone V: Areview of the in vivo and in vitro toxicity of silver and gold particulates: particle attributes and biological mechanisms responsible for the observed toxicity. Crit Rev Toxicol 2010, 40(4):328-346.

12. Semmler M, Seitz J, Erbe F, Mayer P, Heyder J, Oberdörster G, Kreyling WG: Long-term clearance kinetics of inhaled ultrafine insoluble iridium particles from the rat lung, including transient translocation into secondary organs. Inhal Toxicol 2004, 16:453-459.

13. Kim HJ, Yu BP, Chung HY: Molecular exploration of age-related NFkappaB/IKK downregulation by calorie restriction in rat kidney. Free Radic Biol Med 2002, 32:991-1005.

14. Sanhueza J, Valdes J, Campos R, Garrido A, Valenzuela A: Changes in the xanthine dehydrogenase/xanthine oxidase ratio in the rat kidney subjected to ischemia-reperfusion stress: preventive effect of some flavonoids. Res Commun Chem Pathol Pharmacol 1992 Nov, 78(2):211-218.

15. Wang H, Joseph JA: Structure-activity relationships of Quercetin in antagonizing hydrogen peroxide-induced calcium dysregulation in PC12 cells. Free Radic Biol Med 1999 Sep, 27(5-6):683-694.

16. Witte MB, Barbul A: Arginine physiology and its implication for wound healing. Wound Repair Regen 2003, 11(6):419-423.

17. Wu G, Jaeger LA, Bazer FW, Rhoads JM: Arginine deficiency in preterm infants: biochemical mechanisms and nutritional implications. J Nutr Biochem 2004 Aug, 15(8):442-451.

18. Stechmiller JK, Childress B, Cowan L: Arginine supplementation and wound healing. Nutr Clin Pract 2005, 20:52-61.

19. Andrew PJ, Mayer B: Enzymatic function of nitric oxide synthases. Cardiovasc Res 1999 Aug, 43(3):521-531.

20. Isenberg JS, Ridnour LA, Espey MG, Wink DA, Roberts DD: Nitric oxide in wound-healing. Microsurgery 2005, 25(5):442-451.

21. Gokce N: Arginineinine and hypertension. J Nutr 2004 134(10 Suppl):2807-2811. 
22. Reyes AA, Karl IE, Klahr S: Role of Arginineinine in health and in renal disease. AJP-Renal Physiol 1994, 267:f331-f346.

23. Higashi Y, Oshima T, Ozono R, Watanabe M, Matsuura H, Kajiyama G: Effects of Arginineinineinine Infusion on Renal Hemodynamics in Patients With Mild Essential Hypertension. Hypertension 1995, 25:898-902.

24. Wang B, Feng WY, Wang TC, Jia G, Wang M, Shi JW, Zhang F, Zhao YL, Chai ZF: Acute toxicological impact of nano-and submicro-scaled zinc oxide powder on healthy adult mice. Toxicol Lett 2006 Feb, 161(2):115-123.

25. Kambe D, Kotani M, Yoshimoto M, Kaku S, Chaki S, Honda K: Effects of Quercetin on the sleep-wake cycle in rats: involvement of gammaaminobutyric acid receptor type $A$ in regulation of rapid eye movement sleep. Brain Res 2010 May, 1330:83-88.

26. El-Missiry MA, Othman Al, Amer MA: Arginine ameliorates oxidative stress in alloxan-induced experimental diabetes mellitus. J App/ Toxicol 2004, 24(2):93-97.

27. Kim N, Kim YJ, Cho DK: Gold nanoparticle-based signal augmentation of quartz crystal microbalance immunosensor measuring $\mathrm{C}$-reactive protein. Curr Appl Phys 2010, 10(4):1227-1230.

28. Yao DF, Wu XH, Zhu Y, Shi GS, Dong ZZ, Yao DB, Wu W, Qiu LW, Meng XY: Quantitative analysis of vascular endothelial growth factor, microvascular density and their clinicopathologic features in human hepatocellular carcinoma. Hepatobiliary Pancreat Dis Int 2005 May, 4(2):220-226.

29. Kaden J: IL-6 determination in serum of kidney graft recipients by a new bedside test: its diagnostic relevance. Transplant Proc 2007 Mar, 39(2):511-513.

30. Moshage H, Kok B, Uuizenga JR, Jansen P: Nitrite and Nitrate Determination in Plasma: A Critical Evaluation. Clin Chim 1995, 41:892-896.

31. Trinder P: Determination of glucose in blood using glucose oxidase with an alternative oxygen acceptor. Ann Clin Biochem 1969, 6:24-25.

32. Moron MS, Depierre JW, Mannervik B: Levels of glutathione, glutathione reductase and glutathione S-transferase activities in rat lung and liver. Biochim Biophys Acta 1979 Jan, 582(1):67-78

33. Smith A, Bruton J: A colour Atlas of histological staining techniques. J Clin Pathol 1978, 31(3):298

34. Jain TK, Reddy MK, Morales MA, Leslie-Pelecky DL, Labhasetwar V: Biodistribution, clearance, and biocompatibility of iron oxide magnetic nanoparticles in rats. Mol Pharm 2008, 5(2):316-327.

35. Burns AA, Vider J, Ow H, Herz E, Penate-Medina O, Baumgart M, Larson SM, Wiesner U, Bradbury M: Fluorescent silica nanoparticles with efficient urinary excretion for nanomedicine. Nano Lett 2009, 9(1):442-448.

36. Schipper ML, lyer $G$, Koh AL, Cheng Z, Ebenstein $Y$, Aharoni A, Keren S, Bentolila LA, Li J, Rao J, Chen X, Banin U, Wu AM, Sinclair R, Weiss S, Gambhir SS: Particle size, surface coating, and PEGylation influence the biodistribution of quantum dots in living mice. Small 2009, 5(1):126-134

37. BeruBe K, Balharry D, Sexton K, Koshy L, Jones T: Combustion-derived nanoparticles: mechanisms of pulmonary toxicity. Clin Exp Pharmacolm Physiol 2007, 34(10):1044-1050.

38. Chen Z, Meng H, Xing G, Chen C, Zhao Y, Jia G, Wang T, Yuan H, Ye C, Zhao F, Chai Z, Zhu C, Fang X, Ma B, Wan L: Acute toxicological effects of copper of engineered nanomaterials. Nat Nanotechnol 2007, 2:469-478

39. Tsou TC, Yeh SC, Tsai FY, Lin HJ, Cheng TJ, Chao HR, Tai LA: Zinc oxide particles induce inflammatory responses in vascular endothelial cells via NF-kB signaling. J Hazard Mater 2010 Nov, 183(1-3):182-188.

40. Fine JM, Gordon T, Chen LC, Kinney P, Falcone G, Beckett WS: Metal fume fever: characterization of clinical and plasma IL- 6 responses in controlled human exposures to zinc oxide fume at and below the threshold limit value. J Occup Environ Med 1997 Aug, 39(8):722-726.

41. Ivanov V, Cha J, Ivanova S, Kalinovsky T, Roomi MW, Rath M, Niedzwiecki A Essential nutrients suppress inflammation by modulating key inflammatory gene expression. Int J Mol Med 2008, 22:731-741.

42. Mostafavi-Pour Z, Zal F, Monabati A, Vessal M: Protective effects of a combination of Quercetin and vitamin E against cyclosporine A-induced oxidative stress and hepatotoxicity in rats. Hepatol Res 2008 Apr, 38 (4):385-392.

43. Behling EB, Sendão MC, Francescato HD, Antunes LM, Costa RS, Bianchi Mde L: Comparative study of multiple dosage of Quercetin against cisplatin-induced nephrotoxicity and oxidative stress in rat kidneys Pharmacol Rep 2006, 58(4):526-532.

44. Karlsen A, Paur I, Bøhn SK, Sakhi AK, Borge Gl, Serafini M, Erlund I, Laake P, Tonstad S, Blomhoff R: Bilberry juice modulates plasma concentration of
NF-kappa B related inflammatory markers in subjects at increased risk of CVD. Eur J Nutr 2010 Sep, 49(6):345-355

45. Ying B, Yang T, Song X, Hu X, Fan H, Lu X, Chen L, Cheng D, Wang T, Liu D, Xu D, Wei Y, Wen F: Quercetin inhibits IL-1 beta-induced ICAM-1 expression in pulmonary epithelial cell line A549 through the MAPK pathways. Mol Biol Rep 2009 Sep, 36(7):1825-1832.

46. Yu ES, Min HJ, An SY, Won HY, Hong JH, Hwang ES: Regulatory mechanisms of IL-2 and IFNgamma suppression by Quercetin in T helper cells. Biochem Pharmacol 2008 Jul, 76(1):70-78.

47. Liu MY, Cheng YJ, Chen CK, Yang BC: Coexposure of lead- and lipopolysaccharide-induced liver injury in rats: involvement of nitric oxide-initiated oxidative stress and TNF-alpha. Shock 2005 Apr, 23(4):360-364

48. Hushmendy S, Jayakumar L, Hahn AB, Bhoiwala D, Bhoiwala DL, Crawford DR: Select phytochemicals suppress human T-lymphocytes and mouse splenocytes suggesting their use in autoimmunity and transplantation. Nutr Res 2009 Aug, 29(8):568-578.

49. Huang CC, Tsai SC, Lin WT: Potential ergogenic effects of Arginineinine against oxidative and inflammatory stress induced by acute exercise in aging rats. Exp Gerontol 2008 Jun, 43(6):571-577.

50. Wu GH, Zhang YW, Wu ZH: Modulation of postoperative immune and inflammatory response by immune-enhancing enteral diet in gastrointestinal cancer patients. World J Gastroenterol 2001 Jun, 7(3):357-362.

51. Kleemann R, Verschuren L, Morrison M, Zadelaar S, van Erk MJ, Wielinga PY, Kooistra T: Anti-inflammatory, anti-proliferative and anti-atherosclerotic effects of Quercetin in human in vitro and in vivo models. Atherosclerosis 2011, 218(1):44-52

52. Pujalté I, Passagne I, Brouillaud B, Tréguer M, Durand E, Ohayon-Courtès $C$, L'Azou B: Cytotoxicity and oxidative stress induced by different metallic nanoparticles on human kidney cells. Part Fibre Toxicol 2011 Mar, 8:10.

53. Pfeilschifter J, Rob P, Mulsch A, Fandrey J, Vosbeck K, Busse R: Interleukin $1 \beta$ and tumour necrosis factor a induce a macrophage-type of nitric oxide synthase in rat renal mesangial cells. Eur J Biochem 1992 Jan, 203(1-2):251-255.

54. Saura M, López S, Rodríguez Puyol M, Rodríguez Puyol D, Lamas S: Regulation of inducible nitric oxide synthase expression in rat mesangial cells and isolated glomeruli. Kidney Int 1995, 47(2):500-509.

55. Markewitz BA, Michael JR, Kohan DE: Cytokine-induced expression of a nitric oxide synthase in rat renal tubule cells. J Clin Invest 1993 May, 91 (5):2138-2143

56. Cook HT, Ebrahim H, Jansen AS, Foster GR, LArginineen P, Cattell V: Expression of the gene for inducible nitric oxide synthase in experimental glomerulonephritis in the rat. Clin Exp Immun 2008, 97 (2):315-320.

57. Ding YH, Luan XD, Li J, Rafols JA, Guthinkonda M, Diaz FG, Ding Y: Exerciseinduced overexpression of angiogenic factors and reduction of ischemia/reperfusion injury in stroke. Curr Neurovasc Res 2004 Dec, 1(5):411-420.

58. Mechtcheriakova D, Schabbauer G, Lucerna M, Clauss M, De Martin R, Binder BR, Hofer E: Specificity, diversity, and convergence in VEGF and TNF-alpha signaling events leading to tissue factor up-regulation via EGR-1 in endothelial cells. FASEB J 2001 Jan, 15(1):230-242.

59. Tonnesen MG, Feng $X$, Clark RA: Angiogenesis in wound healing. J Invest Dermaol Symp Proc 2000, 5:40-46.

60. Verheul HM, Jorna AS, Hoekman K, Broxterman HJ, Gebbink MF, Pinedo HM: Vascular endothelial growth factor-stimulated endothelial cells promote adhesion and activation of platelets. Blood 2000, 96:4216-4221.

61. Lingen MW: Role of leukocytes and endothelial cells in the development of angiogenesis in inflammation and wound healing. Arch Pathol Lab Med 2001, 125:67-71.

62. Sano H, Hosokawa K, Kidoya H, Takakura N: Negative regulation of VEGFinduced vascular leakage by blockade of angiotensin II type 1 receptor. Arterioscler Thromb Vasc Biol 2006 Dec, 26(12):2673-2680.

63. Jackson JR, Seed MP, Kircher CH, Willoughby DA, Winkler JD: The codependence of angiogenesis and chronic inflammation. FASEB J 1997 May, 11(6):457-465.

64. Honkanen EO, Teppo AM, Grönhagen-Riska C: Decreased urinary excretion of vascular endothelial growth factor in idiopathic membranous glomerulonephritis. Kidney Int 2000 Jun, 57(6):2343-2349.

65. Heffernan D, Dudley B, McNeil PL, Howdieshell TR: Local Arginine supplementation results in sustained wound nitric oxide production and 
reductions in vascular endothelial growth factor expression and granulation tissue formation. J Surg Res 2006 Jun, 133(1):46-54.

66. Fukahori M, Ichimori K, Ishida H, Nakagawa H, Okino H: Nitric oxide reversibly suppresses xanthine oxidase activity. Free Radic Res 1994, 21:203-212.

67. Satyanarayana PS, Singh D, Chopra K: Quercetin, a bioflavonoid, protects against oxidative stress-related renal dysfunction by cyclosporine in rats. Meth Find Exp Clin Pharmacol 2001 May, 23(4):175-181.

68. Lin W, Yang S, Tsai S, Huang C, Lee N: Arginineinine attenuates xanthine oxidase and myeloperoxidase activities in hearts of rats during exhaustive exercise. Br J Nutr 2006, 95:67-75.

doi:10.1186/1472-6882-12-60

Cite this article as: Faddah et al: Role of quercetin and arginine in ameliorating nano zinc oxide-induced nephrotoxicity in rats. $B M C$ Complementary and Alternative Medicine 2012 12:60.

\section{Submit your next manuscript to BioMed Central and take full advantage of:}

- Convenient online submission

- Thorough peer review

- No space constraints or color figure charges

- Immediate publication on acceptance

- Inclusion in PubMed, CAS, Scopus and Google Scholar

- Research which is freely available for redistribution 